\title{
Analisis Faktor yang Berhubungan dengan Penggunaan Produk Tembakau Non-Rokok pada Pelajar SMP di Indonesia
}

\section{Factors Associated with Non-Cigarettes Tobacco Products Use among Junior High School Students in Indonesia}

\author{
Ridhwan Fauzi ${ }^{1,2^{*}}$, Siti RiptifahTri Handari ${ }^{1}$ \\ ${ }^{1}$ Fakultas Kesehatan Masyarakat, Universitas Muhammadiyah Jakarta \\ ${ }^{2}$ Ikatan Ahli Kesehatan Masyarakat Indonesia \\ ('rfauzi@umj.ac.id)
}

\begin{abstract}
ABSTRAK
Produk tembakau non-rokok memiliki dampak negatif terhadap kesehatan yang sama seperti rokok konvensional. Namun, remaja umumnya tidak memahaminya. Saat ini, produk tersebut semakin populer dikalangan. Studi ini bertujuan untuk menganalisis faktor yang berhubungan dengan penggunaan produk tembakau non-rokok pada pelajar SMP di Indonesia. Penelitian ini menggunakan desain potong lintang. Sumber data yang digunakan merupakan data sekunder dari Global Youth Tobacco Survey (GYTS) tahun 2014. GYTS merupakan survei berbasis sekolah pada siswa SMP. Data diambil dari tiga regional di Indonesia (Jakarta, Bekasi dan Medan) dari 21 September 2013 sampai 20 Juni 2014. Populasi penelitian ini yaitu seluruh siswa SMP di Indonesia. Metode pengambilan sampel pada penelitian ini menggunakan Multistage Cluster Random Sampling. Total sampel pada penelitian ini sebanyak 5.986 siswa. Data dibobotkan dengan menggunakan SUDAN dan dianalisis menggunakan chi square dan Regresi Logistik Berganda. Hasil penelitian menunjukan bahwa sekitar 3,6\% responden menyatakan pernah menggunakan dalam 30 hari terakhir. Terdapat hubungan bermakna antara penggunaan produk tembakau non-rokok dengan jenis kelamin, kebiasaan merokok konvensional dan sikap nilai $\mathrm{p}<0,001$. Perokok konvensional yang aktif memiliki peluang 12,055 (CI 95\%:7,674-18,937) kali lebih besar untuk menggunakan produk tembakau tersebut dibandingkan dengan bukan perokok.
\end{abstract}

Kata kunci : Produk tembakau non-rokok, GYTS, pelajar

\section{ABSTRACT}

Non-cigarettes tobacco smoking products have similar negative impact to the health as conventional cigarettes. However, most of adolescent are unaware of the problem. Nowdays, the products gain more popularity among youth. This study aims to find out factors associated with non-cigarettes tobacco products (NCTP) use among junior high school students in Indonesia. The study used crossectional design. The source of data were secondary data of the Global Youth Tobacco Survey (GYTS) 2014. GYTS is a school-based survey of junior high school students. Data was obatianed from three regional (Jakarta, Bekasi, and medan) from September 21st 2013 to June 20th2014. The population of study is national representative of junior high school students in Indonesia. The sampling method was multistage cluster random sampling. Total sampling was 5.986 students. Data was weighted by SUDAN and analyzed by chisquare test and multiple logistic regressions. Study revealed that about 3,6\% respondents ever used NCTP in past 30 days. NCTC used was significantly associated with gender, conventional cigarettes smoking status and attitude in $p<0,001$. Students who regularly smoked convenstional cigarettes were 12,055 (CI 95\%: 7,674-18,937) more likely to use NCTP than non smoker.

Keywords : Non-cigarettes tobacco product, GYTS, students

Copyright (C) 2018 Universitas Hasanuddin. This is an open access article under the CC BY-NC-SA license

(https://creativecommons.org/licenses/by-nc-sa/4.0/).

DOI : http://dx.doi.org/10.30597/mkmi.v15i2.5560 


\section{PENDAHULUAN}

Permasalahan epidemi konsumsi tembakau di dunia tidak hanya tingginya penggunaan rokok kovensional tetapi juga merambah pada produk tembakau non-rokok yang mulai digemari seperti shisha atau hookah dan cerutu atau cigar. Studi yang dilakukan di berbagai negara menunjukan penggunakan shisha yang paling tinggi di dunia berada di regional Amerika dan Timur Tengah yaitu sebesar 34,8\% dan 36,8\%. Di Asia Tenggara, prevalensi penggunaan shisha bervariasi antar negara dengan perkirakan rata-rata sebesar $2.8 \% .^{1}$ Selain itu, produk tembakau yang marak digunakan yaitu rokok cerutu. Penelitian berbasis media daring pada 1.546 remaja dan dewasa muda di Amerika Serikat menunjukan bahwa dari total seluruh pengguna produk tembakau aktif, $17 \%$ diantaranya merupakan perokok cerutu. ${ }^{2} \mathrm{Di}$ Regional Asia Tenggara, prevalensi penggunaan produk tembakau non-rokok bervariasi antar negara. Timor Leste merupakan Negara dengan konsumsi tertinggi pada remaja yaitu sebesar $51,6 \%$ sedangkan yang terendah yaitu Maldives $(3,5 \%)$. Belum banyak studi yang representatif secara nasional untuk menggambarkan konsumsi produk ini di Indonesia.

Usia remaja merupakan periode yang paling rentan dalam daur kehidupan manusia. ${ }^{4}$ Separuh pengguna rokok konvensional maupun produk tembakau non rokok mulai mencoba merokok pada usia kurang dari 17 tahun tahun. ${ }^{2}$ Riskesdas 2018 bahkan melaporkan terjadi peningkatan prevalensi perokok usia 10-18 tahun dari 7,2\% pada tahun 2013 menjadi 9,1\% pada tahun 2018.5,6 Pada periode remaja, anatomi otak berubah secara drastis yang menghasilkan tingginya tingkat emosi, impulsifitas dan ingin selalu mencoba hal-hal yang berisiko. Perubahan ini berdampak pada kurangnya kemampuan untuk mengendalikan sistem kognitif. Oleh karena itu, banyak perilaku berisiko pertama kali dilakukan pada periode ini seperti konsumsi rokok, minuman beralkohol dan seks tidak aman. ${ }^{4}$

Remaja biasanya memiliki persepsi yang salah tentang keamanan produk tembakau nonrokok. Mereka beranggapan bahwa produk ini lebih aman dan diterima secara sosial dibandingkan rokok konvensional. Faktanya, Asap yang dihasilkan oleh produk ini memiliki kesamaan kandungan racun seperti yang terdapat pada rokok konvensional. ${ }^{7}$ Berbagai studi menunjukan bahwa produk tembakau non-rokok menganung zat berbahaya dan sebagian diantaranya karsinogenik seperti polycyclic aromatic hydrocarbons (PAHs), karbon monoksida (CO), volatile aldehydes, TSNA (tobacco spesific nitrosamine), dan masih banyak logam berat lainnya. ${ }^{89}$ Zat ini memiliki efek yang sangat serius pada kesehatan seperti penyakit jantung dan pembuluh darah, penyakit paru dan kanker. ${ }^{8}$ Selain dampak yang ditumbulkan oleh asap hasil pembakaran tembakau, produk tembakau non-rokok seperti waterpipe meningkatkan risiko penularan penyakit. Studi yang dilakukan di Saudi Arabia menunjukan bahwa ditemukan 55 jenis bakteri pada alat untuk menggunakan shisha terdiri dari 28 jenis bakteri gram positif dan 27 gram negative. Dua diantaranya diidentifikasi sebagai bakteri staphylococcus Aureus, dan Klebsiella Pneumoniae. Bakteri tersebut diketahui sebagai penyebab pneumonia yang resisten terhadap antibiotik. ${ }^{10}$ Penggunaan produk tembakau non rokok tidak hanya berdampak pada kesehatan tetapi juga ekonomi. Penelitian di Amerika Serikat pada tahun 2010 menunjukan bahwa angka kematian akibat konsumsi rokok cerutu secara reguler telah menyebabkan kematian premature pada 9.000 penduduk Amerika Serikat yang berakibat pada potensi tahun produktif lebih dari 140.00 tahun dengan nilai ekonomi diperkirakan 23 miliar Dollar Amerika. ${ }^{11}$

Faktor lain yang berkontribusi penting dalam mendorong remaja untuk mengonsumsi produk tembakau non rokok yaitu kebiasaan merokok konvensional, dan sikap terhadap produk tembakau non rokok. Berbagai penelitian menunjukkan bahwa remaja menyukai produk tembakau non rokok seperti shisha karena atraktif, romantik, menyengkan, popular, fashionable dan diterima secara sosial. Remaja juga sering kali membandingkan produk tembakau non rokok dengan rokok konvensional. Produk tersebut dinilai lebih atraktif dan menarik dibandingkan dengan rokok konvensional. Asap yang ditimbulkan oleh shisha juga tidak terlalu mengganggu jika dihirup oleh orang sekitar. Selain itu, penggunaan shisha umumnya dilakukan secara berkelompok sehingga dapat menjadi alternatif yang lebih murah untuk jalan bersama teman dibandingkan dengan mengha- 
biskan malam di bar yang tentunya mahal. ${ }^{12}$

Meskipun penelitian tentang dampak produk tembakau non-rokok terhadap kesehatan di dunia telah banyak tersedia, akan tetapi regulasi untuk menekan laju konsumsi produk ini masih belum signifikan. ${ }^{13}$ Selain itu, penelitian yang mengangkat permasalahan produk tembakau nonrokok di Indonesia juga masih minim. Oleh karena itu, studi ini bermaksud menganalisis faktor yang berhubungan dengan penggunaan produk tembakau non-rokok pada siswa SMP di Indonesia.

\section{BAHAN DAN METODE}

Penelitian ini menggunakan desain cross-sectional. Penelitan ini dilaksanakan pada 21 September 2013 sampai 20 Juni 2014 yang dilakukan oleh 11 peneliti di bawah supervisi Badan Penelitian dan Pengembangan Kesehatan. Populasi penelitian merupakan seluruh siswa SMP di Indonesia. Total sampel penelitian sebanyak 5.986 siswa usia 14-15 tahun. Metode sampling yang digunakan yaitu kluster dua tahap agar mendapatkan hasil sampel yang dapat merepresentasikan siswa kelas 7, 8, dan 9 secara nasional. Seluruh tipe sekolah termasuk ke dalam kerangka sampel. Pada tahap pertama, sekolah dipilih secara acak berdasarkan probability proportional berdasarkan jumlah murid di regional. Tahap ke dua, pemilihan kelas dari setiap sekolah yang terpilih pada tahap pertama dilakukan secara acak menggunakan metode systematic equal probability sampling. Seluruh siswa dalam kelas terpilih direkrut sebagai subjek penelitian.

Variabel terikat dalam penelitian ini yaitu penggunaan produk tembakau non-rokok (shisha, rokok pipa/cangklong, cerutu) dalam 30 hari terakhir, sedangkan variabel bebas terdiri dari usia, uang saku, kebiasaan merokok konvensional, dan sikap terhadap produk tembakau. Kebiasaan merokok konvensional dikategorikan ke dalam 3 yaitu bukan perokok, perokok saat ini (siswa yang me-rokok dalam 30 hari terakhir) dan mantan perokok (responden yang pernah merokok tetapi tidak merokok lagi dalam 30 hari terakhir). Variabel sikap diukur dengan responden tanggapan responden tentang produk tembakau membuat orang merasa nyaman dalam merayakan sebuah pesta, dapat menambah teman, dan terihat lebih atraktif yang diukur dengan skala 1-3. Responden yang memiliki skor median $(\geq 7)$ dikategorikan memiliki sikap negatif terhadap penggunaan produk tembakau Pengambilan data dilakukan dengan metode self administered. Prosedur pengambilan data dilakukan dengan mempertimbangkan kerahasiaan siswa identitas siswa (anonymous). Data kemudian dianalisis dengan uji chi square dan analisis multivariat dengan uji regresi logistik berganda.

\section{HASIL}

Proporsi responden laki-laki sebanyak $50,8 \%$ dan proporsi responden yang berumur kurang dari atau sama dengan 12 tahun sebesar $20,8 \%$, kelompok umur 13 tahun sebesar 35,6\%, dan lebih dari sama dengan 14 tahun sebanyak 43,6\%. Berdasarkan jumlah uang saku yang dite- rima per hari, responden yang memiliki uang saku sebesar kurang dari atau sama dengan 11.000 rupiah, seki$\operatorname{tar} 11.000$ - 30.000, dan lebih dari 30.000 berada dikisaran $30 \%$. Berdasarkan status penggunaan produk tembakau responden. Sekitar $27 \%$ responden menyatakan pernah menggunakan rokok konvensional. Adapun responden yang pernah merokok konvensional, tetapi tidak merokok lagi dalam 30 hari terakhir sebesar 9,6\%. Berdasarkan

Tabel 1 Karakteristik Responden Penelitian

\begin{tabular}{lcc}
\hline \multicolumn{1}{c}{ Karakteristik } & n & \% \\
\hline $\begin{array}{l}\text { Usia (tahun) } \\
\leq 12\end{array}$ & 1,248 & 20,8 \\
13 & 2.130 & 35,6 \\
$\quad \geq 14$ & 2.607 & 43,6 \\
Jenis kelamin & & \\
$\quad$ Perempuan & 2.939 & 49,2 \\
$\quad$ Laki-laki & 3.041 & 50,8 \\
Uang saku (Rp) & & \\
$\quad \leq 11.000$ & 2.225 & 37,3 \\
$\quad 11.001-30.000$ & 1.884 & 31,5 \\
$\quad \geq 30.001$ & 1.863 & 31,2 \\
Penggunaan Rokok & & \\
Konvensional & 4.144 & 73 \\
$\quad$ Tidak & 548 & 9,6 \\
$\quad$ Mantan & 987 & 17,4 \\
$\quad$ Saat ini & & \\
Penggunaan Produk & & \\
Tembakau non Rokok & 5.580 & 93,4 \\
$\quad$ Tidak & 184 & 3 \\
$\quad$ Mantan & 212 & 3,6 \\
$\quad$ Saat ini & & \\
\hline Sin & & \\
\hline
\end{tabular}

Sumber: Data Primer, 2017 
Tabel 2. Analisis Bivariat Penggunaan Produk Tembakau Non-rokok

\begin{tabular}{|c|c|c|c|c|}
\hline \multirow[t]{2}{*}{ Variabel } & \multicolumn{2}{|c|}{$\begin{array}{l}\text { Penggunaan Produk Tembakau } \\
\text { Non-rokok (30 hari Terakhir) }\end{array}$} & \multirow{2}{*}{$p$} & \multirow{2}{*}{ OR (CI: 95\%) } \\
\hline & Ya & Tidak & & \\
\hline \multicolumn{5}{|l|}{ Usia (tahun) } \\
\hline$\leq 12$ & $22(1,8)$ & $1.124(98,2)$ & & 1 \\
\hline 13 & $55(2,6)$ & $2.075(97,4)$ & 0,129 & $1,469(0,894-2,416)$ \\
\hline$\geq 14$ & $135(5,2)$ & $2.468(94,8)$ & $<0,001$ & $3,008(1,91-4,736)$ \\
\hline \multicolumn{5}{|l|}{ Jenis Kelamin } \\
\hline Laki-Laki & $184(6,1)$ & $2.852(93,9)$ & $<0,001$ & $6,705(4,49-10,012)$ \\
\hline Perempuan & $28(1)$ & $2.910(99)$ & & 1 \\
\hline \multicolumn{5}{|l|}{ Uang Saku (Rp.) } \\
\hline$\leq 10.000$ & $93(4,2)$ & $2.131(95,8)$ & 0,035 & $1,439(1,025-2,02)$ \\
\hline $10.000-30.000$ & $64(3,4)$ & $1.816(96,6)$ & 0,435 & $1,157(0,802,1,669)$ \\
\hline$>30.000$ & $55(3)$ & $1.808(97)$ & & 1 \\
\hline \multirow{2}{*}{\multicolumn{5}{|c|}{$\begin{array}{l}\text { Kebiasaan Merokok } \\
\text { Konvensional }\end{array}$}} \\
\hline & & & & \\
\hline Tidak & $35(0,8)$ & $4.107(99,2)$ & & 1 \\
\hline Mantan & $13(2,4)$ & $536(97,6)$ & 0,001 & $2,868(1,504-5,47)$ \\
\hline Saat ini & $144(14,6)$ & $841(85,4)$ & $<0,001$ & $20,395(13,966-29,783)$ \\
\hline \multicolumn{5}{|l|}{ Sikap } \\
\hline Positif & $119(4,8)$ & $2.351(95,2)$ & $<0,001$ & $1,889(1,429-2,497)$ \\
\hline Negatif & $90(2,6)$ & $3.359(97,4)$ & & 1 \\
\hline
\end{tabular}

Sumber: Data Primer, 2017

status penggunaan produk tembakau non-rokok, sekitar 3,4\% responden menyatakan pernah menggunakan dalam 30 hari terakhir sedangkan 93,4\% siswa menyatakan belum pernah menggunakan produk tembakau non-rokok (Tabel 1).

Sekitar 5,2\% responden yang berusia $>14$ tahun yang merupakan pengguna saat ini. Pada usia yang lebih muda yaitu kurang dari 12 tahun dan 13 tahun menunjukan bahwa sekitar 1,8\% dan $2,6 \%$ responden yang berstatus pengguna saat ini. Hasil uji statistik dapat disimpulkan bahwa terdapat hubungan yang bermakna antara usia dengan status penggunaan produk tembakau nonrokok pada nilai $\mathrm{p}<0,001$ (Tabel 2).

Sebanyak $6,1 \%$ responden laki-laki menyatakan menggunakan produk tembakau non-rokok dalam 30 hari terakhir. Pada perempuan, hanya $1 \%$ responden dikategorikan sebagai pengguna saat ini. Hasil analisa data menunjukan bahwa terdapat hubungan yang bermakna antara jenis kelamin dan status penggunaan produk tembakau non-rokok dengan nilai $\mathrm{p}<0,001$ sedangkan pada variabel uang saku, tidak ditemukan hubungan yang bermakna. Sementara itu, hasil chi square test menunjukkan bahwa terdapat hubungan yang bermakna antara besaran uang saku dengan peng- gunaan produk tembakau non-rokok dalam 30 hari terakhir. Kebiasaan merokok konvensional juga memiliki hubungan yang signifikan dengan penggunaan produk tembakau non-rokok $(\mathrm{p}<0,001)$. Sekitar $14,8 \%$ siswa yang merokok saat ini juga menggunakan produk tembakau non-rokok dalam 30 hari terakhir. Adapun siswa yang belum pernah merokok konvensional tapi menggunakan produk tembakau non-rokok yaitu sebesar $0,8 \%$. Studi ini juga menunjukan terdapat hubungan bermakna antara sikap dengan status penggunaan produk tembakau non-rokok $(p<0,001)$. Terdapat $4,8 \%$ siswa yang memiliki sikap positif merupakan pengguna produk tembakau non-rokok, hanya $2,6 \%$ siswa yang bersikap negatif yang menggunakanya (Tabel 2).

Hasil analisis multivariat menunjukan terdapat hubungan yang bermakna antara jenis kelamin, status merokok konvensional dan sikap terhadap penggunaan produk tembakau non-rokok. Status merokok merupakan prediktor yang paling kuat dalam mendorong seseorang utuk menjadi perngguna produk tembakau non-rokok. Perokok konvensional yang aktif memiliki peluang 12,055 (CI 95\%:7,674-18,937) kali lebih besar untuk menjadi pengguna produk tembakau non-rokok 
Tabel 3. Analisis Multivariat Penggunaan Produk Tembakau Non-rokok

\begin{tabular}{lcc}
\hline Variabel Independen & AOR & CI 95\% \\
\hline Usia* & & \\
$\leq 12$ & 1 & \\
13 & 1,202 & $0,7-2.062$ \\
$\quad \geq 14$ & 1,755 & $1,067-2,888$ \\
Jenis Kelamin* & & \\
$\quad$ Laki-Laki & 2.18 & $1,277-3,723^{*}$ \\
$\quad$ Perempuan & 1 & \\
Merokok Konvensional & & \\
$\quad$ Tidak & 1 & \\
$\quad$ Mantan & 2,040 & $1,038-4,012^{*}$ \\
$\quad$ Saat ini & 12,055 & $7,674-$ \\
Sikap* & & $18,937^{* * *}$ \\
$\quad$ Positif & 1,642 & $1,208-2,231^{*}$ \\
$\quad$ Negatif & 1 & \\
\hline
\end{tabular}

${ }^{*} \mathrm{p}<0,01 ; * * \mathrm{p}<0,001$; uang saku tidak masuk model akhir $(\mathrm{p}>0.05)$.

dibandingkan dengan yang bukan perokok (Tabel $3)$.

\section{PEMBAHASAN}

Penelitian ini menunjukan bahwa terdapat hubungan yang bermakna antara usia, jenis kelamin, status merokok dan sikap terhadap penggunaan produk tembakau non-rokok. Studi ini menunjukan proposi penggunaan produk tembakau non-rokok yang terus meningkat seiring dengan bertambahnya usia. Studi ini sejalan dengan sebuah penelitian longitudinal yang dilakukan pada siswa Irbid, Jordania yang menunjukan bahwa penggunaan shisha pertama kali terjadi pada usia 14 tahun ke atas. ${ }^{14}$ Penelitian lain di Cleveland Amerika Serikat juga menunjukan bahwa pertama kali menggunakan cerutu rata-rata terjadi pada usia 15,1 tahun. ${ }^{15}$ Tingginya inisiasi penggunaan produk tembakau non-rokok pada kelompok umur tersebut juga dapat mengindikasikan bahwa konsumsi produk tersebut secara sosial dianggap bukan suatu permasalahan. Hal ini didorong rendahnya pemahaman masyarakat tentang bahaya yang ditimbulkan dari produk tembakau non-rokok. Jika dibandingkan dengan produk rokok konvensional, produk tembakau nonrokok dianggap jauh lebih aman. ${ }^{16}$ Oleh karenanya, tidak heran jika orang tua jauh lebih khawatir anaknya merokok konvensional dibandingkan dengan produk tembakau non-rokok.
Penelitian ini menemukan bahwa proporsi penggunaan produk tembakau non-rokok pada siswa laki-laki jauh lebih besar dibandingkan dengan siswa perempuan. Hasil tersebut sejalan dengan berbagai penelitian yang menunjukan bahwa peluang laki-laki untuk menggunakan produk tembakau lebih besar dari pada perempuan. ${ }^{17}$ Studi yang dilakukan oleh Wong, dkk di Malaysia pada tahun 2016 juga menunjukan bahwa laki-laki memiliki peluang 1.438 lebih besar untuk menggunakan shisha dibandingkan dengan perempuan. ${ }^{18}$ Peningkatan proporsi penggunaan tembakau pada perempuan tetap perlu diwaspadai. Berbagai studi menemukan bahwa jumlah pengguna produk tembakau pada perempuan semakin meningkat setiap tahunnya. ${ }^{13}$ Pasar rokok pada laki-laki yang mulai jenuh mendorong industri rokok untuk menyasar kelompok perempuan. Penggunaan produk tembakau juga dimanfaatkan oleh industri rokok untuk membangun citra dalam mengekspresikan kebebasan, emansipasi, dan keterbelakangan. Beberapa produk tidak hanya menggunakan perempuan sebagai model, tetapi juga menggunakan warna, simbol dan semboyan yang akrab di telinga kaum perempuan. ${ }^{19}$ Hal ini dikonfirmasi oleh studi yang dilakukan pada remaja di Amerika Serikat menunjukkan bahwa terdapat hubungan yang bermakna antara body image dan attractiveness dengan penggunaan zat adiktif. ${ }^{20}$ Selain itu, Produk tembakau non rokok juga memiliki cita rasa yang dapat mendorong orang yang belum pernah menggunakan produk tembakau untuk mencobanya. Cita rasa ini memberi kesan bahwa produk seperti ini tidak berbahaya. Studi yang dilakukan oleh Kostygina, dkk pada dokumen internal industri rokok menunjukan bahwa secara sistematis mereka berupaya untuk mengaburkan bahaya produk tembakau dengan menggunakan berbagai varian rasa yang bertujuan untuk merekrut calon perokok baru terutama perempuan dan remaja. ${ }^{21}$

Penelitian ini menggunakan variabel uang jajan sebagai proxy untuk mengukur hubungan tingkat ekonomi dengan penggunaan produk tembakau non-rokok. Meskipun tidak ditemukan hubungan yang bermakna pada variabel uang jajan dalam model akhir, akan tetapi dalam analisis bivariat menunjukan siswa yang memiliki uang jajan Rp. 10.000 per hari kurang memiliki peluang yang lebih besar untuk menggunakan produk 
tembakau non-rokok dibandingkan dengan siswa yang memiliki uang jajan sebesar 30.000 per hari. Penelitian ini sesuai dengan yang dilakukan di Rwanda yang menunjukan bahwa prevalensi mahasiswa penggunaan produk tembakau non-rokok lebih besar pada masyarakat dengan tingkat sosial ekonomi rendah. ${ }^{22}$ Penelitian lain di Amerika Serikat juga menunjukan penggunaan produk tembakau lebih tinggi pada mahasiswa dengan latar belakang pendidikan keluarga yang rendah (proxy dari tingkat ekonomi). ${ }^{23}$ Tingkat ekonomi tinggi sangat berkaitan dengan tingkat literasi, pengetahuan dan kesadaran yang juga lebih baik tentang menjaga kesehatan dibandingkan dengan masyarakat yang memiliki tingkat ekonomi lebih rendah. ${ }^{24}$

Penelitian ini juga menemukan bahwa terdapat hubungan yang bermakna antara sikap dengan penggunaan produk tembakau non-rokok. Siswa yang menggunakan produk tembakau nonrokok memiliki sikap yang positif terhadap produk tembakau sebagaimana penelitian terdahulu yang telah mengemukakan hal yang serupa. ${ }^{25}$ Iklan rokok memiliki dampak yang besar dalam mengubah persepsi siswa akan bahaya penggunaan produk tembakau. Studi yang dilakukan pada remaja di Malaysia menunjukan bahwa dengan merokok mereka merasa lebih dewasa, menjadi lebih tentang, dan dewasa sebagaimana yang dicitrakan oleh iklan produk tembakau. ${ }^{26}$ Selain itu, industri rokok juga menggunakan berbagai macam cara untuk mendapatkan calon perokok baru salah satunya dengan memasarkan produk tembakau non rokok seperti little cigar dan cigarillos yang ditambah varian rasa seperti permen, vanilla dan chrery sangat ampuh dalam mengubah persepsi remaja akan potensi bahaya yang ditimbulkan oleh tembakau. ${ }^{21}$

Penelitian ini menunjukan bahwa terdapat hubungan yang bermakna antara kebiasaan merokok dengan penggunaan produk tembakau nonrokok. Studi ini juga menunjukan bahwa sekitar $14 \%$ pengguna tembakau non-rokok tidak pernah merokok konvensional sama sekali. Kondisi ini menimbulkan kekhawatiran bahwa produk tembakau non-rokok akan menjadi pintu masuk kecanduan konsumsi produk tembakau. Kuat dugaan terdapat hubungan dosis response antara konsumsi rokok dengan penggunaan produk tumbakau non-rokok. ${ }^{17}$ Sebuah studi kualitatif pada remaja pengguna shisha di London juga menyebutkan bahwa produk alternatif seperti shisha dan rokok elektronik sangat berpotensi mendorong para remaja yang sebelumnya tidak pernah merokok konvensional untuk mencoba menggunakannya karena dinilai lebih aman dan dapat diterima secara sosial. ${ }^{27}$ Selain itu, siswa yang menggunakan dua produk tembakau berbeda juga berpotensi untuk terpapar bahaya rokok yang cukup besar. Selain itu, berbagai studi telah menunjukan produk tembakau non-rokok juga mendorong terjadinya kecanduan nikotin sebagaimana produk rokok konvensional. Tembakau non-rokok juga memiliki tingkat risiko untuk terkena penyakit sama dengan rokok konvensional. ${ }^{9}$

Disparitas antar daerah yang tinggi dapat menyebabkan gambaran persamalahan di tingkat nasional belum tentu sama dengan yang terjadi di daerah tertentu. Selain itu, penelitian ini juga belum menganalisis variabel lain yang dalam studi lain memberikan pengaruh yang besar pada pola konsumsi produk tembakau seperti pengaruh teman, lingkungan, dan orang tua. Akan tetapi, penelitian ini merupakan studi representatif tingkat nasional sehingga dapat memberikan gambaran besar permasalahan penggunaan produk tembakau di Indonesia.

\section{KESIMPULAN DAN SARAN}

Hasil penelitian menunjukan bahwa terdapat hubungan yang bermakna antara penggunaan produk tembakau non-rokok dengan jenis kelamin, kebiasaan merokok konvensional dan sikap. Penelitian ini juga menyimpulkan bahwa jumlah pengguna produk tembakau non-rokok cukup tinggi. Oleh karena itu, diperlukan upaya yang serius dari pemerintah untuk melakukan edukasi bahaya tembakau non-rokok mengingat remaja menilai bahwa produk ini tidak berbahaya jika dibandingkan dengan perokok konvensional aktif. Selain itu, peraturan perundangan yang berkaitan dengan pengendalian tembakau saat ini masih belum mengakomodir produk tembakau non-rokok sehingga hal tersebut berpotensi dimanfaatkan untuk membuyarkan peraturan Kawasan Tanpa Rokok (KTR) yang telah berjalan diberbagai daerah. 


\section{UCAPKAN TERIMAKASIH}

Kami mengucapkan terimakasih kepada Universitas Muhammadiyah Jakarta yang telah membiayai penelitian ini. Pemberian hibah tidak mempengaruhi hasil penelitian.

\section{DAFTAR PUSTAKA}

1. Jawad, M., Charide, R., Waziry, R., Darzi, A., Ballout, R. A. \& Akl, E.A. The Prevalence and Trends of Waterpipe Tobacco Smoking: A Systematic Review. PLOS ONE. 2017; 13(2): e0192191.

2. Soneji, S., Sargent, J. \& Tanski, S. Multiple Tobacco Product Use among US Adolescents and Young Adults. Tob. Control. 2016; 25(2): 174-180.

3. Sinha, D. N., Palipudi, K. M., Rolle, I., Asma, S. \& Rinchen, S. Tobacco Use among Youth and Adults in Member Countries of SouthEast Asia Region: Review of Findings from Surveys under the Global Tobacco Surveillance System. Indian J. Public Health. 2011; 55(3): 169-176.

4. US Department of Health and Human Services. Preventing Tobacco Use Among Youth and Young: A Report of the Surgeon General. Atlanta: Department of Health and Human Services, Centers for Disease Control and Prevention, National Center for Chronic Disease Prevention and Health Promotion, Office on Smoking and Health; 2012.

5. Kementerian Kesehatan. Riset Kesehatan Dasar 2018. Jakarta: Kementerian Kesehatan RI; 2018.

6. Kementerian Kesehatan. Riset Kesehatan Dasar 2013. Jakarta: Kementerian Kesehatan RI; 2013.

7. Maziak, W., Taleb, Z. B., Bahelah, R., Islam, F., Jaber, R., Auf, R. \& Salloum, R. G. The Global Epidemiology of Waterpipe Smoking. Tob Control. 2015; 24(supl 1): i3-i10.

8. Schivo, M., Avdalovic, M. V. \& Murin, S. Non-Cigarette Tobacco and the Lung. Clinic Allerg Immunol. 2014; 46(1); 34-53.

9. Monzer, B., Sepetdjian, E., Saliba, N. \& Shihadeh, A. Charcoal Emissions as A Source of $\mathrm{CO}$ and Carcinogenic PAH in Mainstream Narghile Waterpipe Smoke. Food and Chemical Toxicology. 2008; 46(9): 2991-2995.
10. Alaidarous, M., Alanazi, M. \& Abdel-Hadi, A. Isolation, Identification, and Atimicrobial Susceptibility of Bacteria Associated with Waterpipe Contaminants in Selected Area of Saudi Arabia. BioMed Res. Int. 2017; 2017.

11. Nonnemaker, J., Brian, R., Patricia, H., Anna, M. \& Benjamin, A. Mortality and Economic Costs From Regular Cigar Use in the United States, 2010. Am. J. Public Health. 2014; 104(9): e86-e91.

12. Akl, E. A., Ward, K. D., Bteddini, D., Khaliel, R., Alexander, A. C., Lofti, T., Alaouie, H. \& Afifi, R. A. The Allure of the Waterpipe: A Narrative Review of Factors Affecting the Epidemic Rise in Waterpipe Smoking among Young Persons Globally. Tob. Control. 2015; 24 (supl 1): i13-i21.

13. TCSC-IAKMI. Fakta Tembakau Indonesia 2014. Jakarta: Tobacco Control Support Center-Ikatan Ahli Kesehatan Masyarakat Indonesia; 2014.

14. MCKelvey, K., Attonito, J., Madhivanan, P., Jaber, R., Yi, Q., Mzayek, F. \& Maziak, W. Determinants of Waterpipe Smoking Initiation among School Children in Irbid, Jordan: A 4-Year Longitudinal Analysis. Drug Alcohol Depend. 2014; 142: 307-313.

15. Antognoli, E., Gonzalez, K., S., Trapl, E., Cavallo, D., Lavanty, B., Lim, R. \& Flocke, S. Cigarettes, Little Cigars, and Cigarillos: Initiation, Motivation, and Decision-Making. Nicotine Tob. Res. 2018; 20(Suppl 1): S5-S11.

16. Caroline, C., Ward, K. D., Maziak, W., Shihadeh, A. \& Eissenberg, T. Waterpipe Tobacco Smoking: An Emerging Health Crisis in The United States. Am. J. Health Behav. 2010; 34(4): 275-285.

17. Ramji, R., Arnetz, J., Nilsson, M., Jamil, H., Norstorm, F., Maziak, W., Wiklund, Y. \& Arnetz, B Determinants of Waterpipe Use amongst Adolescents in Northern Sweden: A Survey of Use Pattern, Risk Perception, and Environmental Factors. BMC Res. Notes. 2015; 8(441).

18. Wong, L. P., Haridah, A., Aghamohammadi, N., Aghazadeh, S. \& Hoe, V. C. W. Shisha Smoking Practices, Use Reasons, Attitudes, Health Effects and Intentions to Quit among Shisha Smokers in Malaysia. Int. J. Environ. 
Res. Public. Health. 2016; 13(7): 726-740.

19. Amos, A. \& Haglund, M. From Social Taboo to 'Torch of Freedom': The Marketing of Cigarettes to Women. Tob. Control. 2000; 9(1): 3-8.

20. Winter, V. R., Kennedy, A. K. \& O’Neill, E. Adolescent Tobacco and Alcohol Use: The Influence of Body Image. J. Child Adolesc. Subst. Abuse. 2017 26(3): 219-228.

21. Kostygina, G., Glantz, S. A. \& Ling, P. M. Tobacco Industry Use of Flavours to Recruit New Users of Little Cigars and Cigarillos. Tob. Control. 2016; 25(1): 66-74.

22. Omotehinwa, O. J., Japhets, O., Damascene, I. J. \& Habtu, M. Shisha Use among Students in A Private University in Kigali city, Rwanda: Prevalence and Associated Factors. BMC Public Health. 2018;18(1):713.

23. Sterling, K., Berg, C. J., Thomas, A. N., Glantz, S. A. \& Ahluwalia, J. S. Factors Associated With Small Cigar Use Among College Students. Am. J. Health Behav. 2013;37(3): 325-333.
24. Lim, K. H., The, C. H., pan, S., Ling, M. Y., Yusoff, M. F. M., Ghazali, S. M., Kee, C. C., Lim, K. K., Chong, K. H. \& Lim, H. L. Prevalence and Factors Associated with Smoking among Adults in Malaysia: Findings from the National Health and Morbidity Survey (NHMS) 2015. Tob. Induce Dis. 2018;16 (January): 1

25. Page, R. M., Huong, N. T., Chi, H. K. \& Tien, T. Q. Social Normative Beliefs About Smoking Among Vietnamese Adolescents. Asia Pac. J. Public Health. 2012;24(1):68-81.

26. Kin, F. \& Lim, K. Y. Tobacco Advertising and Smoking Amongst Adolescents: A Qualitative Study in Malaysia. Bangkok; South East Asia Tobacco Control Alliance (SEATCA): 2003..

27. Kotecha, S., Jawad, M. \& Illiffe, S. Knowledge, Attitudes and Beliefs towards Waterpipe Tobacco Smoking and Electronic Shisha (e-shisha) among Young Adults in London: A Qualitative Analysis. Prim. Health Care Res. Dev. 2016;17(2):166-174. 